\title{
Adenovirus 5-CD40 Ligand
}

National Cancer Institute

\section{Source}

National Cancer Institute. Adenovirus 5-CD40 Ligand. NCI Thesaurus. Code C2493.

An adenovirus vector eng ineered to produce CD40 ligand. For use as a possible gene

therapy agent. May induce apoptosis through the TNF pathway. 